\title{
PREEMPTION OF STATE LAW NOTICE PROVISIONS GOVERNING THE RECOVERY OF ATTORNEYS' FEES BY SECTION 506(b) OF THE BANKRUPTCY CODE
}

With increasing frequency, bankruptcy courts are facing the question of the effect of state law on an oversecured creditor's apphication for attorneys' fees pursuant to section 506(b) of the Bankruptcy Code. ${ }^{1}$ The issue arises most visibly in those states that have passed statutes that limit a creditor's ability to recover attorneys' fees even when contractual provisions entitle the creditor to attorneys' fees if forced to take action to collect the note. A few states refuse to recognize attorneys' fees obligations in promissory notes, declaring them void and unenforceable. ${ }^{2}$ However, most state laws restricting the availability of attorneys' fees take the form of notice statutes, which require a creditor to provide a certain number of days' notice of its intent to enforce the attorneys' fees clause before the clause will be held valid. ${ }^{3}$

1. 11 U.S.C. $\S 506$ (b) (Supp. II 1984).

2. Statutes in two states declare contractual attorneys' fees provisions in bonds, notes, mortgages, bills of exchange, and other evidences of debt void and unenforceable on policy grounds. See KAN. STAT. ANN. § 58-2312 (1983); N.D. CENT. CODE § 28-26-04 (1974). These statutes have been severely criticized, see Note, Recovery of Attorney Fees in Kansas, 18 WASHBURN L.J. 535, 543-45 (1979), and have been dismissed as anachronistic by some courts, see, eg., In re American Metals Corp., 31 Bankr. 229, 234 \& n.1 (Bankr. D. Kan. 1983). However, both statutes have recently been upheld by state courts. See Farmers Union Oil Co. v. Maixner, 376 N.W.2d 43, $48-49$ (N.D. 1985); Iola State Bank v. Biggs, 233 Kan. 450, 459-64, 662 P.2d 563, 572-75 (1983). Whatever their continuing vitality, this note does not directly address the question whether these statutes should be preempted in the context of a bankruptcy proceeding.

3. For example, N.C. GEN. STAT. § 6-21.2(5) (1981) provides in pertinent part:

The holder of . . . any other such security agreement which evidences both a monetary obligation and a security interest in or a lease of specific goods, or his attorney at law, shall, after maturity of the obligation by default or otherwise, notify the ... party sought to be leeld on said obligation that the provisions relative to payment of attorneys' fees in addition to the "outstanding balance" shall be enforced and that such ... party sought to be held on said obligation has five days from the mailing of such notice to pay the "outstanding balance" without the attorneys' fees. If such party shall pay the "outstanding balance" in full before the expiration of such time, then the obligation to pay the attorneys' fees shall be void, and no court shall enforce such provisions.

Several other states have some form of statutory notice requirement that must be satisfied before a creditor may rightfully collect the attorneys' fees provided for in its contract with the debtor. Georgia's notice statute is very similar to North Carolina's, except that it requires ten days' notice of intent to collect fees. See GA. CODE ANN. § 13-1-11(a) (1982). The new Texas Civil Practice and Remedies Code adopts a thirty-day notice requirement. See TEx. CIV. Prac. \& REM. CODE ANN. $\$ 38.002$ (Vernon 1986). New Jersey provides that attorneys' fees clauses in a note are void unless 
Before the adoption of the Bankruptcy Code in 1978, it was well settled that state law determined the validity of an attorneys' fees agreeinent contained in a promissory note, even in the context of a bankruptcy proceeding. ${ }^{4}$ Since 1978, however, it has been uncertain whether the Bankruptcy Code effected a change in the pre-existing law. This confusion is attributed in part to the language of section 506(b) of the Codeproviding an oversecured creditor the right to collect interest and fees where the underlying agreement provides for their recoverys - which does not clearly address the role of state law in determining the validity of attorneys' fees agreements in bankruptcy. ${ }^{6}$

The lower federal courts have split on the issue. A shiglt majority of the decisions rendered under the new Bankruptcy Code have recognized or held that an oversecured creditor may obtain attorneys' fees under section 506(b) notwitlistanding contrary state law.7 Sucl holdings effectively preempt state attorneys' fee laws in the context of a bankruptcy proceeding. The shight minority of the decisions, however, have recognized or held that state law inust continue to govern the validity of attorneys' fee agreements in bankruptcy. ${ }^{8}$ Only one circuit court of appeals has examined the effect of section $506(\mathrm{~b})$ on state law notice provisions. ${ }^{9}$

the borrower receives fifteen days' notice of intent to sue upon the note. See N.J. STAT. ANN. § 17:11A-53 (West 1984). Mississippi permits recovery of attorneys' fees only where a demand is made thirty days before filing suit. See Miss. CoDE ANN. § 11-53-81 (Supp. 1985). Nuinerous states provide for notice or demand requirements in order to collect attorneys' fees incurred in the collection of sinall claiıns. See, e.g., IDAHO CODE § 12-120(1) (1979); OR. REv. STAT. ANN. $\S 20.080(1)$ (1983).

4. See, e.g., Security Mortgage Co. v. Powers, 278 U.S. 149, 153-54 (1928); In re Morris, 602 F.2d 826, 828 (8th Cir. 1979); ITT-Indus. Credit Co. v. Hughes, 594 F.2d 384, 386-88 (4th Cir. 1979); In re Bain, 527 F.2d 681, 685 (6th Cir. 1975); In re Atlanta Int'1 Raceway, Inc., 513 F.2d 546, 548 (5th Cir. 1975); In re Cipriano, 8 Bankr. 697, 698 (Bankr. D.R.I. 1981); In re Ruck, 4 Bankr. 194, 195 (Bankr. D. Ariz. 1980). See also Manufacturers' Fin. Co. v. McKey, 294 U.S. 442, 448 (1935) ("[T]hat a party is obliged to go into a federal court of equity to enforce an essentially legal right arising upon a contract valid ... under controlling state law does not authorize that court to modify or ignore the terms of the legal obligation upon the claim.").

5. 11 U.S.C. \$ 506(b) (Supp. II 1984).

6. See infra notes $21-22$ and accompanying text.

7. See In re 268 Limited, No. 84-2837, slip. op. at 4 (9th Cir. May 5, 1986); In re Berry Estates, Inc., 47 Bankr. 1004, 1007 (S.D.N.Y. 1985); Longwell v. Banco Mortgage Co., 38 Bankr. 709, 711 (N.D. Ohio 1984); In re Scarboro \& Garnto, 13 Bankr. 439, 442 (M.D. Ga. 1981); In re Rausch, 41 Bankr. 833, 834 (Bankr. D.S.D. 1984); In re Schlecht, 36 Bankr. 236, 238-40 (Bankr. D. Alaska 1983); In re American Metals Corp., 31 Bankr. 229, 234-35 (Bankr. D. Kan. 1983); In re Elmwood Farm, Inc., 19 Bankr. 338, 341 (Bankr. S.D.N.Y. 1982); In re Carey, 8 Bankr. 1000, 100204 (Bankr. S.D. Cal. 1981); In re Smith, 4 Bankr. 12, 13 (Bankr. E.D.N.Y. 1980).

8. See In re Triangle Equip. Co., 26 Bankr. 175, 177-78 (W.D. Va. 1982); In re Dawson, 32 Bankr. 179, 180 (Bankr. W.D. Mo. 1983); In re Banks, 31 Bankr. 173, 175 (Bankr. N.D. Ala. 1982); In re LHD Realty Corp., 20 Bankr. 722, 725 (Bankr. S.D. Ind. 1982); In re Dye Master Realty, Inc., 15 Bankr. 932, 935-36 (Bankr. W.D.N.C. 1981); In re Sholos, 11 Bankr. 782, 784-85 (Bankr. W.D. Pa. 1981).

9. See Unsecured Creditors' Comm. v. Walter E. Heller \& Co., 768 F.2d 580 (4th Cir. 1985). 
This note provides a framework for courts and attorneys faced with the issue whether section 506(b) preempts state law notice provisions. The note studies the language and legislative history of section 506(b), pointing out the inconsistencies and ambiguities that make it difficult to determine congressional intent. ${ }^{10}$ The note then surveys the various rationales advanced by the lower courts in resolving this issue. Using the recent Fourth Circuit case of Unsecured Creditors' Committee v. Walter $E$. Heller \& Co. ${ }^{11}$ to illustrate several of these rationales, the note suggests that a more consistent approach to this issue is needed.12 After examining the legislative history of section 506(b) in light of federal preemption doctrine, ${ }^{13}$ and concluding that contradictory inferences arising from the legislative history preclude an unequivocal determination of congressional intent to preempt state law under 506(b), ${ }^{14}$ the note argues that such a determination is unnecessary to reach the conclusion that state law notice provisions should be preempted under section 506(b). Rather, simce state law notice statutes serve to provide no meanimgful protection to the bankrupt debtor, while creating a procedural burden on the bankruptcy courts and a financial burden on the bankruptcy estate, the state statutes should be preempted in bankruptcy because they interfere with the accomplishment of the policy goals that underlie the Bankruptcy Code. ${ }^{15}$

\section{The History of the Bankruptcy Code and Section 506(b)}

The steady growth in consumer and business bankruptcies during the 1960's and early 1970's led to a series of legislative proposals urging a comprehensive revision of federal bankruptcy law that culminated in 1978 when H.R. $8200^{16}$ was enacted as the Bankruptcy Reform Act. That bill and its Senate companion, S. 2266, ${ }^{17}$ were designed to create a more efficient procedure for the administration of bankruptcies within a

In In re LHD Realty Corp., 726 F.2d 327 (7th Cir. 1984), the United States Court of Appeals for the Seventh Circuit allowed the recovery of late charges by an oversecured creditor pursuant to section 506(b). The court noted that such charges were recoverable under Indiana law and that it therefore would have no ground for denying the creditor recovery of the charges. $I d$. at $333 \&$ $n .8$. The court did not, however, explicitly address the question whether Indiana law was preempted by section 506(b). Id. at 333.

10. See infra notes $16-41$ and accompanying text.

11. 768 F.2d 580 (4th Cir. 1985).

12. See infra notes $42-65$ and accompanying text.

13. See infra notes 66-71 and accompanying text.

14. See infra notes $\mathbf{7 2 - 8 5}$ and aecompanying text.

15. See infra notes $86-105$ and accompanying text.

16. H.R. 8200, 95th Cong., 1st Sess. (1977).

17. S. 2266, 95th Cong., 2d Sess. (1977). 
modernized federal bankruptcy court system. ${ }^{18}$ No fewer than six proposed bills preceded H.R. 8200 and S. 2266 during prior sessions of Congress. ${ }^{19}$ These earlier attempts at revision, however, did not include a provision comparable to section $506(b) .^{20}$

\section{A. The Language of Section 506(b).}

Section 506 of the Bankruptcy Code governs the determination of the secured status of a creditor's claim. Subsection (b), which did not have a counterpart in the former Bankruptcy Act, addresses the availability of interest and fees to an oversecured claimant:

To the extent that an allowed secured claim is secured by property the value of which, after any recovery under subsection (c) of this section, is greater than the amount of such claim, there shall be allowed to the holder of such claim, interest on such claim, and any reasonable fees, costs, or charges provided for under the agreeinent under which such claim arose. ${ }^{21}$

Clearly, the language of section 506(b) does not resolve the question whetlier state law is applicable in determining the validity of contractual attorneys' fees clauses. Because the statute does not explicitly address the question wliether section 506(b) supplants state law, courts have reached a variety of conclusions. ${ }^{22}$

18. See S. REP. No. 989, 95th Cong., 2d Sess. 2-3, reprinted in 1978 U.S. CODE CONG. \& AD. NEws 5787, 5788-89.

19. In the ninety-fourth Congress, Representative Edwards, who served as House fioor manager for H.R. 8200, introduced the proposed statute of the Commission on the Bankruptcy Laws of the United States as H.R. 31, 94th Cong., 1st Sess. (1975), and also introduced the competing proposal of the National Conference of Bankruptcy Judges as H.R. 32, 94th Cong., 1st Sess. (1975). See H.R. REP. No. 595, 95th Cong., 1st Sess. 2, reprinted in 1978 U.S. CoDE CoNG. \& AD. NEws 5963, 5964; Senator Burdick introduced these two proposals in the Senate as S. 236, 94th Cong., 1st Sess. (1975), and S. 235, 94th Cong., 1st Sess. (1975), respectively.

During extensive hearings, the constitutionality of the proposals was questioned because they provided for bankruptcy judges who would not have life tenure pursuant to article III. See Bankruptcy Act Revision, Hearings Before the Subcomm on Civil and Constitutional Rights of the House Comm. on the Judiciary, 94th Cong., 2d Sess. 1943, 2034, 2081-84 (1978) (statement of William T. Plumb, Jr., consultant to the Commission on Bankruptcy Laws of the United States). This constitutional concern prompted further congressional study on the constitutionality of the proposed bankruptcy revision. See Klee, Legislative History of the New Bankruptcy Law, 28 DE PAUL L. REV. 941, 945 (1979). The study led to the formulation of a new bill, H.R. 6, 95th Cong., 1st Sess. (1977), which Representative Edwards introduced in the House in January 1977. After markup, the committee compiled all of its changes into an amendment in the nature of a substitute, H.R. 7330, 95th Cong., 1st Sess. (1977). After revision, H.R. 7330 became H.R. 8200. See Klee, supra, at 945-47.

20. See Staff of Subcomm. on Civil and Constitutional Rights of the House Comm. ON THE Judiciary, 95Th CONG., 1st Sess., Table of DeRIVATION OF H.R. 8200, at 8 (Comm. Print 1977).

21. 11 U.S.C. $\$ 506($ b) (Supp. II 1984).

22. See infra notes 58-65 and accompanying text. 


\section{B. The Legislative History of Section 506(b).}

The legislative history of the Bankruptcy Code-and particularly of section 506(b) - does not remove all doubt concerning the preemptive effect of section 506(b). H.R. 8200 emerged from the House Judiciary Committee on September 8, 1977. At that time, section 506(b) read:

To the extent that an allowed secured claim is secured by property the value of which, after any recovery under subsection (c) of this section, is greater than the amount of such claim, there shall be allowed to the holder of such claim, to the extent collectible under applicable law interest on such claim, and any reasonable fees, costs, or charges provided under the agreement under which such claim arose. ${ }^{23}$

In the accompanying House report, the Judiciary Committee interpreted section 506(b) as "codif[ymg] current law by entitling a creditor with an oversecured claim to any reasonable fees, costs, or charges provided under the agreement under which the claim arose."24 Pre-existing case law estabhshed that contractual attorneys' fee provisions were enforceable in bankruptcy only if valid in accordance with state law. ${ }^{25}$ Moreover, the House version of section 506(b) exphitily incorporated state law. Therefore, one could reasonably infer from the House report that H.R. 8200 would allow an oversecured creditor to recover attorneys' fees under section 506(b) only where such fees were allowable under state law. ${ }^{26}$

Though S. 2266 was a companion bill to H.R. 8200, there were many differences, one of which involved the language of section 506(b). When it emerged from committee, the Senate version provided:

To the extent that an allowed secured claim is secured by property, the value of which, after any recovery under subsection (c) of this section,

23. H.R. 8200, 95th Cong., 1st Sess. $§ 506(b)$ (1977) (emphasis added), reprinted in App. 3 Collier on BANKRUPTCY III-1, 387 (15th ed. 1983) [hereinafter cited as Collier].

24. H. REP. No. 595, 95th Cong., 1st Sess. 356-57, reprinted in 1978 U.S. CODE CoNG. \& AD. NEws 5963, 6312.

25. See supra note 4.

26. See infra note 80 and accompanying text.

H.R. 8200 was first considered by the House on October 27, 1977. See 123 CoNG. REC. 35,438 (1977). The next day, Congressman Danielson introduced a controversial amendment designed to withdraw the article III status of the proposed bankruptcy courts. See id. at 35,673-78. The amendment was adopted, whereupon Congressman Edwards withdrew the bill from further consideration. See id. at 35,692-93.

This activity in the House served to spur action in the Senate, where Senator DeConcini introduced S. 2266 on October 31, 1977. See id. at 36,095. The Senate Judiciary Committee held extensive hearings on S. 2266 during the first session, see Bankruptcy Reform Act of 1978, Hearings Before the Subcomm. on Improvements in Judicial Machinery of the Senate Comm. on the Judiciary on S, 2266 and H.R. 8200, 95th Cong., 1st Sess. (1977), and subsequently incorporated the results of the hearings into an amendment in the nature of a substitute to S. 2266. This amended version was subsequently reported out of committee on July 14, 1978. See S. REP. No. 989, 95th Cong., $2 d$ Sess. 1, reprinted in 1978 U.S. CODE CONG. \& AD. NEws 5787. 
is greater than the amount of such claim, there shall be allowed to the holder of such claim, interest on such claim, and any reasonable fees, costs, or charges provided under the agreement under which such claiin arose. ${ }^{27}$

Unlike the House version of the bill, the Senate version contained no reference to "applicable [state] law."28 It is significant, however, that despite the absence of this language, the Senate Judiciary Committee interpreted section 506(b) as codifying pre-existing law. ${ }^{29}$ The Senate interpretation was essentially identical to the House interpretation of H.R. $8200,,^{30}$ notwithstanding the different language of the two bills. Thus, at the time the Senate committee filed its report, the reasonable inference of congressional intent was that under section 506(b) of S. 2266, state law would continue to determine the validity of the attorneys' fees claims of oversecured creditors. ${ }^{31}$

After the House voted to approve H.R. 8200,32 the Senate amended H.R. 8200 by replacing the text of the bill with that of S. 2266 and passed H.R. 8200 , as amended, by voice vote. ${ }^{33}$ Due perhaps to the lateness of the session and the fear that prolonged negotiation imight jeopardize the possibility of enacting any bankruptcy legislation during the second session, the floor managers apparently decided to forego a formal conference and instead atteinpted to resolve the differences by informal agreeinent. ${ }^{34}$ Congressman Edwards offered an amendment to the Senate version of the bill, which was passed by consent and returned to the Senate. ${ }^{35}$ The Senate concurred in the amendment, offered a final set of amendments, and returned the package to the House for final passage. ${ }^{36}$ A motion to concur in the final Senate amendments passed without objection in the House, and the bill was sent to the President for approval. ${ }^{37}$ Throughout the final ainendment process, no changes were made in the

27. S. 2266, 95th Cong., 2d Sess. $§ 506(\mathrm{~b})$ (1977), reprinted in App. 3 ColliER, supra note 23, at VII-1, 394.

28. See supra note 23 and accompanying text.

29. Subsection (b) codifies current law by entitling a creditor with an oversecured claim to any reasonable fees (including attorneys' fees), costs, or charges provided under the agreement under which the claim arose. These fees, costs, and charges aare [sic] secured claims to the extent that the value of the collateral exceeds the amount of the underlying claim.

S. REP. No. 989, 95th Cong., 2d Sess. 68, reprinted in 1978 U.S. CODE CoNG. \& AD. NEws 5787, 5854.

30. See supra note 24 and accompanying text.

31. See infra note 80 and accompanying text.

32. See 124 CONG. REc. 1783 (1978).

33. Id. at 28,284 .

34. See Klee, supra note 19, at 954; see also 124 CoNG. REC. 34,144 (1978) (statement of Rep. Edwards).

35. 124 CONG. REC. $32,350-420$ (1978).

36. Id. at $33,989-4,019$.

37. Id. at $34,143-45$. 
text of the Senate version of section 506(b). ${ }^{38}$

To this point, the legislative history of section $506(\mathrm{~b})$ seems relatively straightforward. However, the floor statements made by Congressinan Edwards and Senator DeConcini, the inanagers of the bill, in reporting the apparent compromise version of H.R. 8200 to their respective houses of Congress, contradicted the interpretation of section 506(b) evidenced in both the House and Senate reports. In reporting to the House, Congressman Edwards stated:

Section 506(b) of the House amendment adopts language contained in the Senate amendment and rejects language contained in H.R. 8200 as passed by the House. If the security agreement between the parties provides for attorneys' fees, it will be enforceable under title II [sic], notwithstanding contrary law, and is recoverable from the collateral after any recovery under section 506(c)..$^{39}$

Senator DeConcini used identical language in reporting H.R. 8200 to the Senate. ${ }^{40}$

These floor stateinents seem to contemplate the preemption of state attorneys' fees laws under section 506(b). However, the language of the Senate version of section 506(b) never changed, and Senator DeConcini offered no explanation for-or recognition of-the change in interpretation from the original Senate Judiciary Coinmittee report filed less than three inonths earlier. ${ }^{41}$ The remainder of the legislative record also provides no explanation for the change in interpretation of the provision. Because the Senate committee report and the floor statements present contradictory interpretations of the same language, it is difficult to discern an unmistakable congressional intent concerning the role of state law under section 506(b).

\section{JUDICIAL APPROACHES}

Recently, in Unsecured Creditors' Committee v. Walter E. Heller \& Co. ${ }^{42}$ the United States Court of Appeals for the Fourth Circuit addressed the question whether section 506(b) supplants state attorneys' fees laws. The procedural history of Heller demonstrates the divergent judicial approaches to resolving this issue.

38. Compare supra note 21 and accompanying text (present version of section 506(b)) with supra note 27 and accompanying text (S. 2266 as it emerged from committee). The word "for" following "provided" was added in a technical amendment in 1984. Act of July 10, 1984, Pub. L. No. 98-353, § 448(a), 98 Stat. 333, 374.

39. 124 CONG. REC. 32,398 (1978) (emphasis added).

40. Id. at 33,997 .

41. Compare supra text accompanying note 39 (floor statement) with supra note 29 and accompanying text (coinmittee report explaining that section 506(b) codified current law).

42. 768 F.2d 580 (4th Cir. 1985). 
The Heller case arose out of the bankruptcy proceedings of the debtor K.H. Stephenson Supply Co. ("Stephenson"). Stephenson had executed a promissory note in favor of Walter E. Heller \& Co. ("Heller") that granted Heller a secured interest in Stephenson's inventory and accounts receivable exceeding the face amount of the note. The note also provided that Heller, as an oversecured creditor, could collect attorneys' fees up to fifteen percent of the debt. ${ }^{43}$

After Stephenson petitioned for reorganization, Heller filed a claim with the United States bankruptcy court under section 506(b), seeking to recover the attorneys' fees and expenses provided for in the note. The Unsecured Creditors' Committee objected to an award of attorneys' fees, asserting that Heller had not complied with the applicable Nortli Carolina law governing the recovery of attorneys' fees. ${ }^{44}$ The bankruptcy court overruled this objection and held that notice would have been futile given Steplienson's inability to repay the debt, and that this futility reheved Heller of its obligation to provide the five-day notice required by the North Carolina statute. ${ }^{45}$ On rehearing, however, the bankruptcy court held that Heller had to comply with the North Carolina statute, notwithstanding the futility of compliance. Yet the court awarded attorneys' fees to Heller, finding that Heller had satisfied the notice requirement when it filed its original proof of claim. ${ }^{46}$

The district court, in reviewing the decision of the bankruptcy court, determined that Heller, in filing its claim, had not sufficiently conıphed witl the notice provisions of Nortli Carolina law. 47 The court then examined the legislative history of section 506(b) in order to determine whether Congress had intended to preempt state law governing the collection of attorneys' fees. ${ }^{48}$ The court did not find the legislative history of section 506(b) conclusive. ${ }^{49}$ Reasoning from the language of section 506(b) and the policies underlying the Bankruptcy Code, the court concluded that state law governed the validity of attorneys' fees provisions.

\section{The note provided that:}

Each maker and endorser further agrees, jointly and severally, to pay all costs of collections, including a reasonable attorney's fee of $15 \%$ in case the principal of this note or any interest thereon is not paid at the respective maturity thereof, or in case it becomes necessary to protect the security thereof, whether suit be brought or not.

Unsecured Creditors' Comm. v. Walter E. Heller \& Co., No. C-82-1282-G, slip op, at 2 (M.D.N.C.

Feb. 17, 1984), rev'd, 768 F.2d 580 (4th Cir. 1985).
44. Heller, 768 F.2d at 581-82.

45. Id. at 582 .

46. Id.

47. Unseeured Creditors' Comm. v. Walter E. Heller \& Co., No. C-82-1282-G, slip op. at 18 (M.D.N.C. Feb. 17, 1984), rev'd, 768 F.2d 580 (4th Cir. 1985).
48. Id. at 6.

49. Id, at 7 . 
Accordingly, the court denied Heller's petition for attorneys' fees because it had failed to comply with the five-day notice requirement of North Carolina law. ${ }^{50}$

The Fourth Circuit reversed, remanding to the bankruptcy court for an award of reasonable attorneys' fees to Heller. ${ }^{51}$ The majority opinion, written by Judge Ervin, indicated that under pre-Bankruptcy Reform Act case law, state law governed the validity of attorneys' fees agreements.52 Finding the words of the statute unhelpful in deciding whether Congress intended to preempt state law, the court turned to the legislative history of section 506(b). The court attributed the "confusion" in the legislative history to the different language of the two bills, ${ }^{53}$ but held that the confusion could be resolved by examining the fate of the House version of section 506(b)..$^{54}$ The court then proceeded to assigu determinative weight to the floor statements of Congressman Edwards and Senator DeConcini, which purported to reject the "to the extent collectible under applicable law" language of the House version..$^{55}$ The majority thus concluded that Congress, in rejecting the House version of section 506(b), intended to supplant existing law that upheld attorneys' fees agreements only if they were valid and enforceable under state law. ${ }^{56}$ Concurring in the result, Judge Widener felt that the bankruptcy court had correctly decided the case after the first hearing-that state law governed, but comphiance with the state's notice requirenent was unnecessary because the bankrupt debtor, unable to repay the debt, could not have avoided hitigation even if it had received the notice. ${ }^{57}$

The various approaches adopted by the judges involved in the Heller case reflect the lack of judicial consensus in resolving the issue. Some courts, like the Heller inajority, have rehed exclusively on the legislative history of the statute in holding that section 506(b) supplants state law. ${ }^{58}$ Others have determined that the statute itself provides sufficient evidence

50. Id. at 18.

51. Heller, $768 \mathrm{~F} .2 \mathrm{~d}$ at 585 .

52. Id. at 582 .

53. Id. at 584 .

54. Id. at 585.

55. The Heller court initially asserted that it would not automatically give determinative weight to the floor statements in its search for the legislative intent underlying section 506(b). Id. at 583. Because these statements are the only evidence in the legislative history that supports the inference that Congress intended to supplant pre-existing law, however, the court could not have reached its result without assigning determinative weight to the floor statements.

56. Id. at 585 .

57. Id. at 585-86.

58. See In re Berry Estates, Inc., 47 Bankr. 1004, 1007 (S.D.N.Y. 1985); In re Scarboro \& Garnto, 13 Bankr. 439, 442 (M.D. Ga. 1981); In re Schlecht, 36 Bankr. 236, 238-40 (Bankr. D. Alaska 1983); In re Carey, 8 Bankr. 1000, 1004 (Bankr. S.D. Cal. 1981). 
of congressional intent to abrogate state law. ${ }^{59}$ A number of courts have simply stated that section 506(b) allows such fees without any discussion of whether state law applies, or have relied on citations to other cases in place of independent analysis. 60

Nor have the courts holding that state law is not supplanted by section 506(b) apphed a uniform approach. The bankruptcy judge in Heller held that state law governed, and that filing a proof of claim in bankruptcy would satisfy a state law notice provision. ${ }^{61}$ The district judge in Heller relied on the language of section 506(b) in reaching the conclusion that state law governed attorneys' fees agreeinents. ${ }^{62}$ Some courts have simply rehed on pre-Bankruptcy Reform Act case law for support. ${ }^{63}$ Others have decided that the statute, legislative history, and existing case law clearly require the apphication of state law. ${ }^{64}$ Finally, one district court, on the basis of the legislative history, reached the novel conclusion that if a security agreement provides for attorneys' fees, they are to be determined in accordance with state law, unless they are not recoverable under state law, in which case they inay be allowed as a matter of federal law. ${ }^{65}$

\section{A Framework For Preemption of State LAW Notice Provisions}

The variation in approaclies einployed by the lower federal courts can perhaps be attributed to the fact that courts have generally failed to address the issue in terms of preemption doctrine; courts have failed to ask whether section 506(b) preempts the apphication of state attorneys' fees laws in the context of a bankruptcy proceeding. 66 Under the bank-

59. See Longwell v. Banco Mortgage Co., 38 Bankr. 709, 711 (N.D. Ohio 1984).

60. In re Elmwood Farm, Inc., 19 Bankr. 338, 341 (Bankr. S.D.N.Y. 1982); In re Smith, 4 Bankr. 12, 13 (Bankr. E.D.N.Y. 1980).

61. See supra note 46 and accompanying text.

62. See supra note 50 and accompanying text.

63. See In re Triangle Equip. Co., 26 Bankr. 175, 177 (W.D. Va. 1982); In re Dawson, 32 Bankr. 179, 180 (Bankr. W.D. Mo. 1983); In re Banks, 31 Bankr. 173, 175 (Bankr. N.D. Ala. 1982); In re Dye Master Realty, Inc., 15 Bankr. 932, 935-36 (Bankr. W.D.N.C. 1981).

64. See, e.g., In re Sholos, 11 Bankr. 782, 784-85 (Bankr. W.D. Pa. 1981).

65. In re Virginia Foundry Co., 9 Bankr. 493, 497 (W.D. Va. 1981). Other courts have cited this decision as authority for the proposition that state laws govern the validity of fees provisions. See, e.g., In re LHD Realty Corp., 20 Bankr. 722, 725 (Bankr. S.D. Ind. 1982).

66. The United States Court of Appeals for the Ninth Circuit recently held that section 506(b) "preempts" state law governing the availability of attorneys' fees as part of a secured claim and bankruptcy courts should determine the reasonableness of a claim for attorneys' fees rather than enforcing a contractual fee provision valid under state law. See In re 268 Limited, No. 84-2837, slip op. at 4-7 (9th Cir. May 5, 1986). Like the Heller court, the 268 Limited court found the floor statements to be determinative of Congress's intent to displace state law. Id. at 6-7. Despite holding that section 506(b) preempts state law, the 268 Limited court did not examine section 506(b) in light 
ruptcy clause of the Constitution, ${ }^{67}$ Congress clearly has the power, if it so chooses, to preempt state law governing the validity of contractual attorneys' fees provisions sought to be enforced by oversecured creditors in bankruptcy courts. ${ }^{68}$ Yet the mere fact that Congress could preempt these state laws does not justify an inference or presumption that it did so, because "[c]onsideration under the Supremacy Clause starts with the basic assumption that Congress did not intend to displace state law."69 This is particularly true where, as in section 506(b), the federal statute does not facially reflect congressional intent to preempt. The Supreme Court has frequently declared that "[p]re-emption of state law by federal statute or regulation is not favored ' $\mathrm{m}$ the absence of persuasive reasons-either that the nature of the regulated subject matter permits no other conclusion, or that the Congress has unmistakably so ordained." "'70 Thus, state laws governing the validity of an oversecured creditor's attorneys' fees agreement should be preempted only if the legislative history of section 506(b) unmistakably reflects preemptive intent, or if the nature of attorneys' fees or the nature of federal bankruptcy regulation is such that there is no room for state law under section 506(b). Alternatively, section 506(b) may preempt state attorneys' fees laws where they "stand as

of the established thresholds for federal preemption-whether congressional intent is unmistakable, whether Congress has occupied the regulatory field, or whether there is an unavoidable conflict between the federal and state laws. See infra notes 70-71 and accompanying text.

67. Congress has the power "[t]o establish . . . uniform Laws on the subject of Bankruptcies throughout the United States." U.S. ConST. art. I, § 8, cl. 4.

68. See Butner v. United States, 440 U.S. 48, 54 (1979) ("The constitutional authority of Congress ... would clearly encompass a federal statute defining the mortgagee's interest in the rents and profits earned by property in a bankrupt estate."); United States v. Kras, 409 U.S. 434, 447 (1973) (congressional power over bankruptcy is plenary and exclusive); Wright v. Union Cent. Life Ins. Co., 304 U.S. 502, 518 (1938) ("Property rights do not gain any absolute inviolability in the bankruptcy court because created and protected by state law. . . . [I]f Congress is acting within its bankruptcy power, it nuay authorize the bankruptcy court to affect these property rights . . . ."); Penn Terra Ltd. v. Departnuent of Envtl. Resources, 733 F.2d 267, 272 (3d Cir. 1984) ("Congress, under its Bankruptcy power, certainly has the constitutional prerogative to pre-empt the States, even in their exercise of police power . . . "); Johnson v. First Nat'l Bank, 719 F.2d 270, 273 (8th Cir. 1983) (where Congress chooses to exercise its bankruptcy power, contrary state laws must give way), cert. denied, 465 U.S. 1012 (1984).

69. Maryland v. Louisiana, 451 U.S. 725, 746 (1981). See also Midlantic Nat'1 Bank v. New Jersey Dept. of Envtl. Protection, 106 S. Ct. 755, 761 (1984) ("Title 28 U.S.C. $\S$ 959(b) provides additional evidence that Congress did not intend for the Bankruptcy Code to pre-empt all state laws.").

70. Chicago \& N.W. Transp. Co. v. Kalo Brick \& Tile Co., 450 U.S. 311, 317 (1981) (quoting Florida Line \& Avocado Growers, Inc. v. Paul, 373 U.S. 132, 142 (1963)); accord Hayfield N.R.R. Co. v. Chicago \& N.W. Transp. Co., 467 U.S. 622, 632-33 (1984); Coninionwealth Edison Co. v. Montana, 453 U.S. 609, 634 (1981); Alessi v. Raybestos-Manhattan, Inc., 451 U.S. 504, 522 (1981); see also Penn Terra Ltd. v. Departntent of Envtl. Resources, 733 F.2d 267, 273 (3d Cir. 1984) ("Where the traditional police power of the State is deened to "be withdrawn by Congress in bankruptcy legislation, evidence of that withdrawal in fit language should be found within the act.' ") (quoting In re Chicago Rapid Trans. Co., 129 F.2d 1, 5 (7th Cir.), cert denied, 317 U.S. 683 (1942)). 
an obstacle to the accomplishment and execution of the full purposes and objectives of Congress."71

\section{A. Congressional Intent to Preempt State Law Notice Provisions.}

Because the language of the statute is ambiguous, any holding that Congress unmistakably intended to preempt state law notice provisions must be founded in an analysis of the legislative history of section 506(b). Courts that have held that Congress intended to abrogate state law, such as the Heller court, have relied solely on the legislative history, despite its ambiguities, witlout examining other potential bases for that result. ${ }^{72}$ As discussed previously, the Heller inajority attributed the confusion surrounding section $506(\mathrm{~b})$ to the different language used in the original version of H.R. $8200 .{ }^{73}$ The court proceeded to assign determinative weight to the floor statements, ${ }^{74}$ concluding that they effectively resolved the ambiguity caused by the different language of the two bills. ${ }^{75}$

A careful analysis of the legislative history, however, suggests that the resolution is not so simple. Contrary to the analysis of the courts adopting the Heller rationale, it was the floor statements, not the different. language of the imitial bills, that introduced confusion and inconsistency into tlie legislative history. ${ }^{76}$ In construing a statute, a court should look to determine the probable intent of Congress. ${ }^{77}$ At the time of the filing of the Senate committee report, the intent of botli louses had been clearly expressed by both judiciary committees. Each version of section 506(b) was interpreted as merely codifying pre-existing law,

71. Capital Cities Cable, Inc. v. Crisp, 467 U.S. 691, 698-99 (1984) (quoting Hines v. Davidowitz, 312 U.S. 52, 67 (1941)); accord Perez v. Campbell, 402 U.S. 637, 649 (1971).

72. Critics of the ever-increasing use of legislative history in judicial interpretation of statutes are frequently most vocal where, as in the case of section 506(b), the legislative history can arguably be construed to support conflicting inferences. Cf. American Petroleum Inst. v. EPA, 661 F.2d 340, 355 (5th Cir. 1981) ("A singularly unhelpful source of information, legislative history always contains self-serving statements that support either side of an argument and most points between."); Jackson, The Meaning of Statutes: What Congress Says or What the Court Says, 34 A.B.A. J. 535, 538 (1948) ("It is a poor cause that cannot find some plausible support in legislative history ....."); Mangum, Legislative History in the Interpretation of Law: an Illustrative Case Study, 1983 B.Y.U. L. REV. 281, 304 ("Legislative history is often-perhaps almost always-a weak reed to lean upon in deciding the ineaning of ambiguous statutory language."); Wald, Some Observations on the Use of Legislative History in the 1981 Supreme Court Term, 68 Iowa L. REv. 195, 214 (1983) ("It sometimes seems that citing legislative history is . . . akin to looking over a crowd and picking out your friends.").

73. See supra note 53 and accompanying text.

74. See supra note 55 and accoinpanying tcxt.

75. Heller, 768 F.2d at 585.

76. See supra notes $39-41$ and accoinpanying text.

77. See, e.g., Philbrook v. Glodgett, 421 U.S. 707, 713 (1975) ("Our objective in a case [calling for construction of a statute] is to ascertain the congressional intent and give effect to the legislative will."). 
notwithstanding the different language contained in the two bills. ${ }^{78}$ Thus, it is reasonable to suggest that at the time the Senate committee filed its report there was no confusion to be resolved as to the intent of Congress in enacting section 506(b). Rather, the confusion began when the floor statements, in no way reflecting the content of the committee reports, inexplicably indicated that section 506(b) provided for attorneys' fees notwithstanding contrary law. 79

There is no readily available evidence that explains this inconsistency and apparent change of interpretation. There is no evidence that the committee members contemplated a federal standard; indeed, the committee reports suggest otherwise. ${ }^{80}$ There is no evidence of markup or any informal changes made after the filing of the committee reports that might justify or explain such a change. There was no debate concerning section 506(b) during floor consideration of the Bankruptcy Reform Act. Because there was no fornal conference, there is no conference report that might reflect the reasons for changing the previously expressed interpretation of section 506(b) (if such a change were

78. See supra notes 24,29 and accompanying text.

79. The content of the floor statements simply does not follow from a reconstruction of the history of the Senate version of section 506(b) to that point. The Senate report reflected the Senate's intent to codify pre-existing law. See supra note 29 and accompanying text. The first sentence of the floor statement recognized that section 506(b) as enacted adopted the Senate version of the bill. See supra notes $39-40$ and accompanying text. Thus, the logical conclusion from these two statements would be that the bill as enacted codified pre-existing law. The second sentence of the floor statement, which the Heller court found determinative, does not logically follow from the prior expression of congressional intent contained in the Senate report.

80. It is untenable to propose that Congress was confused as to the status of the pre-existing law in this area, as one court argned in holding that section 506(b) establishes a federal standard for the recovery of attorneys' fees. See In re American Metals Corp., 31 Bankr. 229, 234 (Bankr. D. Kan. 1983). In interpreting federal statutes, a court should presume that Congress knew and understood the state of the law at the time of the consideration of the statute. See Cannon v. University of Chicago, 441 U.S. 677, 696-97 (1979) ("It is always appropriate to assume that our elected representatives, hike other citizens, know the law ... ."); Exploration Co. v. United States, 247 U.S. 435, 449 (1918) ("When Congress passed the act in question the rule of Bailey v. Glover [88 U.S. (21 Wall.) 342 (1874)] was the established doctrine of this court. It was presumably enacted with the ruling of that case in mind."); United States v. Zappola, 677 F.2d 264, 268 (2d Cir.) (presuning that Congress was aware of settled interpretation of state extortion laws), cert. denied, 459 U.S. 866 (1982); International Union of the United Ass'n of Journeyman and Apprentices of the Plumbing and Pipefitting Indus. v. NLRB, 675 F.2d 1257, 1260 (D.C. Cir. 1982) (Congress knew precisely what state laws it validated in passing Taft-Hartley Act), cert. denied, 459 U.S. 1171 (1983); United States v. PATCO, 653 F.2d 1134, 1138 (7th Cir.) (court can presume that Congress is aware of settled judicial constructions of existing law), cert. denied, 454 U.S. 1083 (1981); Kansas City v. Federal Pac. Elec. Co., 310 F.2d 271, 275 (8th Cir.) ("[I]t is to be assumed that Congress was aware of established rules of law applicable to the subject matter of the statute ...."), cert. denied, 371 U.S. 912 (1962). 
intended). ${ }^{81}$ Furthermore, the legislative history is devoid of any stated policy considerations that would justify or require a federal standard under section 506(b). Analyzed in its entirety, the legislative history provides no conclusive explanation for any cliange of interpretation.

This is not to suggest that the interpretation of the Heller court is wholly indefensible. Certainly, the floor statements are explicit, and floor stateinents by inanagers of legislation have generally been considered worthy of substantial weight in the interpretation of statutes. ${ }^{82}$ Yet although these floor stateinents provide plausible support for a federal standard under section 506(b), they also create an inconsistency in an otlierwise clear legislative history and provide no explanation for the alleged departure froin the interpretation contained in the explicit committee reports. ${ }^{83}$ Therefore, it is also possible to conclude, as have some

81. Indeed, from the similarity of the committee reports concerning the interpretation of section 506(b), see supra notes 24,29 and accompanying text, it appears that there was no difference of interpretation or intent on which to compromise.

82. Courts have often referred to floor statements of managers of legislation and accorded them great or determinative weight in statutory interpretation. See, e.g., Lewis v. United States, 445 U.S. 55, 63 (1980); Simpson v. United States, 435 U.S. 6, 13 (1978); Johansen v. United States, 343 U.S. 427, 437 (1952); Duplex Printing Press Co. v. Deering, 254 U.S. 443, 474-77 (1921); Mills v. United States, 713 F.2d 1249, 1252-53 (7th Cir. 1983), cert. denied, 464 U.S. 1069 (1984). These references, however, have usually been accorded determinative weight only where the committee reports were not explicit on the disputed issue, see, e.g., Duplex, 254 U.S. at 475; where the committee report was not previously submitted to the committee members, see Chicago, M. St. P. \& P.R.R. v. Acme Fast Freight, Inc., 336 U.S. 465, 475 (1949); where the provision at issue was introduced by floor amendment and was thus not interpreted in hearings or committee reports, see Lewis, 445 U.S. at 62 ; Simpson, 435 U.S. at $13 \&$ n. 7 ; or where the statements were made in response to a question during debate which specifically addressed the issue to be determined, see Duplex, 254 U.S. at 475; Mills, 713 F.2d at 1252-53. None of these situations is present in the case of section 506(b).

83. An unexplained change in the interpretation of a bill should not be entitled to determinative weight in construmg a statute or the intent of the legislature in enacting it. See Trailmobile Co. v. Whirls, 331 U.S. 40, 61 (1947) ("[T]he most important committee changes relied upon were made without explanation. The interpretation of statutes cannot safely be made to rest upon mute intermediate legislative maneuvers.") (footnotes omitted); Drummond Coal Co. v. Watt, 735 F.2d 469, 474 (11th Cir. 1984) ("Unexplained changes made in committee are not reliable indicators of congressional intent.").

The statements from Trailmobile and Drummond Coal are simply court-stated guidelines for construction and, of course, do not determine the proper construction of section 506(b). Moreover, the context is not strictly analogous because the apparent change in the interpretation of section 506(b) occurred outside of committee. See supra note 34 and accompanying text.

The underlying premise of Trailmobile, however, suggests that because the alleged change in the interpretation of section 506(b) occurred outside of committee, the floor statements should not be treated as unmistakable proof of congressional intent. The changes in Trailmobile and Drummond Coal were made in committee, see Trailmobile, 331 U.S. at 61; Drummond Coal, 735 F.2d at 474, where the changes were presumably carefully considered by the committee members. $C f$. Schwegmann Bros. v. Calvert Distillers Corp., 341 U.S. 384, 395 (1951) (Jackson, J., concurring) (committee reports "presumably are well considered and carefully prepared"). Still, the courts refused to accord the unexplained changes determinative interpretive weight. See Trailmobile, 331 U.S. at 61; Drummond Coal, 735 F.2d at 474. Where, as in the case of section 506(b), the alleged change did not even occur in committee and there is no other documented explanation, a court should, under 
courts, ${ }^{84}$ that the legislative history does not reflect a congressional intent to preempt state law in the unmistakable manner that federal preemption doctrine requires. ${ }^{85}$

\section{B. Obstructing the Accomplishment of Objectives Underlying the Bankruptcy Code.}

Because of the uncertainty surrounding the legislative history, it is surprising that courts, in considering section 506(b), have not looked toward one of the alternative rationales for preemption-that state law may be preempted where it stands "as an obstacle to the accomplishment and execution of the full purposes and objectives of Congress." 86 An

the analysis of Trailmobile, be hesitant to assign such a "mute intermediate legislative maneuver" determinative weight in construction.

84. See supra notes 49,65 and accompanying text.

85. Under federal preemption doctrine, see supra note $\mathbf{7 0}$ and accompanying text, "[p]re-emption of state law by federal statute or regnlation is not favored ... [unless] Congress has unmistakably so ordained." Chicago \& N.W. Transp. Co. v. Kalo Brick \& Tilc Co., 450 U.S. 311,317 (1981). Accord Alessi v. Raybestos-Manhattan, Inc., 451 U.S. 504, 522 (1981); DeCanas v. Bica, 424 U.S. 351, 356-57 (1976); Florida Lime \& Avocado Growers, Inc. v. Paul, 373 U.S. 132, 142 (1963). Where legislative history does not unmistakably reflect congressional intent to supersede state law, courts should be hesitant to rely solely on legislative history in finding that state law is preempted. For example, in UAW v. Russell, 356 U.S. 634 (1958), the Supreme Court addressed the issue whether state jurisdiction over unfair labor practices was preempted by the Taft-Hartley Act and jurisdiction vested in the National Labor Relations Board. The Court, despite the presence of a House committee report which explicitly declared that "by the Labor Act Congress pre-empts the field . . insofar as commerce within the ineaning of the Act is concerned," see H.R. REP. No. 245, 80th Cong., 1st Sess. 44 (1947), held that state jurisdiction to award damages resulting from strike related incidents and activities "cannot fairly be said to be pre-empted without a clearer declaration of congressional policy than we find here." Russell, 356 U.S. at 646 (emphasis added).

Likewise, in New York State Dept. of Social Servs. v. Dublino, 413 U.S. 405 (1973), the appellees extensively cited legislative history for the proposition that the Federal Work Incentive Program Act preempted the New York Work Rules as they applied to recipients of federal funds. See Brief of Appellees at 21-23, 28-31, New York State Dept. of Social Servs. v. Dublino, 413 U.S. 405 (1973). Despite these voluminous citations, the Court simply quoted one representative statement from the brief and concluded that it was "ambiguous as to a possible congressional intention to supersede all state work programs." Dublino, 413 U.S. at 416 (footnote omitted). The court stated that "far more would be required to show the 'clear manifestation of [congressional] intention' which must exist before a federal statute is held "to supersede the exercise' of state action." Id. at 417 (quoting Schwartz v. Texas, 344 U.S. 199, 202-03 (1952)).

See also Holtzman v. Schlesinger, 484 F.2d 1307, 1314 (2d Cir. 1973) ("Resort to legislative materials is not permissible where they are contradietory or ambiguous.") (citing NLRB v. Plasterer's Local Union No. 79, 404 U.S. 116, 129 n.24 (1971), which stated that "legislative materials, if 'without probative value, or contradictory, or ambiguous,' should not be permitted to control the customary meaning of words") (quoting United States v. Dickerson, 310 U.S. 554, 562 (1940)), cert. denied, 416 U.S. 936 (1974).

86. See supra note 71 and accompanying text. Such a determination typically involves a consideration and comparison of the purposes of the laws or regulatory schemes. See, e.g., In re Quanta Resources Corp., 739 F.2d 912, 921-22 (3d Cir. 1984) (goal of state law-to protect public health by regulating disposal of toxic wastes-was sufficiently meritorious as not to be preempted by abandonment power granted to trustee by 11 U.S.C. $\$ 554$ (1982), even though clean-up of the wastes would 
examination of the policies underlying the Bankruptcy Code and the effects of forced compliance with state law notice provisions indicates that forced compliance has such a deleterious effect on the bankruptcy estate and the bankruptcy system that state law notice provisions should be preempted im bankruptcy, where they do not further the underlying state policies of debtor protection. ${ }^{87}$ Thus, resort to this branch of preemption doctrine serves to render a resolution of the tangled legislative history of section 506(b) unnecessary.

State law notice provisions serve the laudable purpose of protecting debtors by allowing them one final opportunity to pay their outstanding debt without incurring attorneys' fees. ${ }^{88}$ Such statutes are often motivated by the historical distaste of American courts for awarding attorneys' fees to hitigants. ${ }^{89}$ Certainly, the strong state policies of debtor protection underlying these statutes should not be ignored in deterinining whether state law is preempted by section 506(b).

Because the bankrupt debtor invariably lacks sufficient funds to repay his debt, however, compliance with state law notice provisions tends to be futile in the bankruptcy context. ${ }^{90}$ Where the debtor lacks funds to repay the debt, the few days' grace provided by the notice statute becomes a rather meaningless protection. The maxim that "the law does

result in substantial expenditures that would deplete assets of the bankruptcy estate), aff'd sub nom. Midlantic Nat'l Bank v. New Jersey Dept. of Envtl. Protection, 106 S. Ct. 755 (1986); Rogers v. Larson, 563 F.2d 617, 622-26 (3d Cir. 1977) (Virgin Islands job protection statute preempted by Immigration and Nationality Act ("INA") despite emphasis in territory's statute on job protection, because territory's statute emphasized proteeting jobs of citizens, and INA emphasized protection of aliens), cert. denied, 439 U.S. 803 (1978); Mariniello v. Shell Oil Co., 511 F.2d 853, 855-59 (3d Cir. 1975) (New Jersey's "good cause" restriction on franchisor's right to terminate franchise does not compromise goals of federal scheme of trademark regulation embodied in the Lanham Act and thus is not preempted).

87. See infra notes 88-105 and accompanying text.

88. See, e.g., Coastal Prod. Credit Ass'n v. Goodson Farms, Inc., 70 N.C. App. 221, 224, 319 S.E.2d 650, 653 (1984).

89. See, e.g., Alyeska Pipeline Serv. Co. v. Wilderness Soc'y, 421 U.S. 240, 247 (1975) ("In the United States, the prevailing litigant is ordmarily not entitled to colleet a reasonable attorneys' fee from the loser."). The notice statute at issue in Heller has been interpreted as "a far-reaching exception to the well-established rule against attorney's fees obligations." Reavis v. Ecological Dev., Inc., 53 N.C. App. 496, 499, 281 S.E.2d 78, 80 (1981); State Wholesale Supply, Inc. v. Allen, 30 N.C. App. 272, 276, 227 S.E.2d 120, 124 (1976).

90. District Judge Bullock, in his order denying Heller's mqtion for reconsideration, recoguized that the utility of the notice provision was impaired in the context of a bankruptcy proceeding: "Since debtors will rarely be able to pay their obligation and avoid the imposition of fees, the benefits flowing from the rule enunciated by this court [requiring compliance with state law] may be largely formalistic with little substantive benefit to be achieved." Unsecured Creditors' Comm. v. Walter E. Heller \& Co., No. C-82-1282-G, at 2 (M.D.N.C. May 16, 1984) (order denying motion for reconsideration). 
not require doing a vam thing"91 lends some support to the argument that notice provisions should be preempted in bankruptcy. At least one court and one leading commentator have cited this futility in concluding that section 506(b) abrogated pre-existing law. ${ }^{92}$

Even assuming, however, that futility alone is an insufficient ground for overriding the strong state policies underlying state notice statutes, such statutes are particularly onerous in bankruptcy because of their deleterious effects on the bankruptcy estate. The filing of a petition in bankruptcy triggers the automatic stay provision of section 362 of the Bankruptcy Code. ${ }^{93}$ The stay, which is extremely broad in scope, "should apply to almost any type of formal or informal action against the debtor or the property of the estate." 94 Because the attorneys' fees of an oversecured creditor are paid out of the bankruptcy estate, the filimg of a notice of intent to collect attorneys' fees as required by state law is an act in violation of the automatic stay,,$^{95}$ and the stay prevents the creditor from giving notice even though notice is required under state law as a precondition to the collection of fees. As a result, the oversecured creditor is forced to go through the process of filing a motion for relief from the autoinatic stay each time it attempts to give notice of intent to collect attorneys' fees as required by state law.

This additional procedural requirement imposes a substantial burden on the bankruptcy courts and the bankruptcy estate. If compliance

91. This argument was advanced by the creditor, and summarily rejected by the court, in ITTIndus. Credit Co. v. Hughes, 594 F.2d 384, 387-88 (4th Cir. 1979).

92. See In re Schlecht, 36 Bankr. 236, 239 (Bankr. D. Alaska 1983); 3 Coll1ER, supra note 23, If 506.05, at 506-47. Judge Widener, concurring in Heller, argued that although state law should generally govern contractual attorneys' fees provisions, notice should have been waived in Heller because of its futility. Heller, 768 F.2d at 586 .

93. 11 U.S.C. $\$ 362$ (a) (1982).

94. 2 COLLIER, supra note $23, \Uparrow 362.04$, at 362-27.

95. See 11 U.S.C. $§ 362(a)(3)$ (1982) (filing of bankruptcy petition stays "any act to obtain possession of property of the estate or of property from the estate"); 11 U.S.C. $\S 362(a)(4)$ (1982) (filing of bankruptcy petition stays "any act to create, perfect, or enforce any lien against property of the estate"). The filing of notice required under state law creates an additional liability upon the debtor and the bankruptcy estate when the debtor fails to repay the debt, and this seems to fall within the category of acts proscribed by these sections. Further, filing of notice of intent to collect attorneys' fees does not fall within the narrow exceptions to the automatic stay elaborated in 11 U.S.C. § 362(b) (1982).

Courts have held that section 362(a) prevents the giving of notice of intent to collect attorneys' fees, see, e.g., Unsecured Creditors' Comm. v. Walter E. Heller \& Co., No. C-82-1282-G, slip op. at 15 (M.D.N.C. Feb. 17, 1984), rev'd 768 F.2d 580 (4th Cir. 1985), and other affirmative acts necessary under state law to secure or enforce claims against the debtor, see, e.g., In re Murphy, 22 Bankr. 663, 665 (Bankr. D. Colo. 1982) (prohibiting a public trustee from issuing a deed on secured property). One commentator has suggested that "[a]s an ordinary rule, the non-debtor party should when in doubt assume that the stay applies and seek relief by appropriate proceedings in the bankruptcy court." 2 CoLLIER, supra note 23 , I 362.04, at 362-35. 
with state law notice provisions is required, an oversecured creditor must satisfy the requirements of a seven step procedure, involving several hearings, to ensure recovery of his attorney's fees. ${ }^{96}$ If, however, the notice requirement is preempted by section 506(b), only three procedural steps, involving only one hearing, are necessary for the creditor to secure his attorney's fees. ${ }^{97}$ A seven-step procedure with multiple hearings places greater burdens on the bankruptcy courts than the more streamlined procedural approach available if state law notice provisions are preempted in bankruptcy. Moreover, a growing majority of courts hold that reasonable attorneys' fees incurred in carrying out each of the necessary procedural steps are compensable. 98 As a resnlt, requiring compliance with the state law notice provision essentially doubles the attorneys' fees ex-

96. The oversecured creditor would (1) file a motion for relief from the automatic stay, see 11 U.S.C. $§ 362$ (d) (1982); (2) attend a hearing on the motion for relief from stay, see id.; (3) prepare an order granting relief from stay when granted; (4) file the notice in accordance with state law; (5) submit an application for attorneys' fees, see 11 U.S.C. $§ 506(b)$ (Supp. II 1984); FED. R. BANKR. P. 2016(a); (6) attend a hearing on the fee application; (7) prepare an order granting fees.

97. The oversecured creditor would (1) submit an application for attorneys' fees, see 11 U.S.C. § 506(b) (Supp. II 1984); FED. R. BANKR. P. 2016(a); (2) attend a hearing on the fce application; (3) prepare an order granting fees. It would be unnecessary to obtain rehef from a stay under this scenario because the Bankruptcy Code authorizes the filing of the fee application. See 11 U.S.C. $\S$ 506(b) (Supp. II 1984); FED. R. BANkR. P. 2016(a).

98. The Ninth Circuit recently held that bankruptcy counsel are entitled to compensation for the time and effort spent in preparing fee applications:

To require counsel to devote considerable time to the preparation of fee applications, but to demand that they absorb the substantial cost associated therewith, would be to ignore the direct inandate of section 330 (a) that reasonable compensation be provided for all "actual, necessary" services rendered by bankruptcy counsel. ... We have long required an attorney to file a detailed account of the legal services he provided ... in order to recover any compensation at all for his services. It would be unduly penurious to require such an accounting without granting reasonable compensation.

In re Nucorp Energy, Inc., 764 F.2d 655, 659 (9th Cir. 1985) (per curiam) (quoting Rose Pass Mines, Inc. v. Howard, 615 F.2d 1088, 1093 (5th Cir. 1980)) (emphasis in original). Accord In re Braswell Motor Freight Lines, 630 F.2d 348, 351 (5th Cir. 1980); In re G.A.C. Corp., 14 Bankr. 252, 255, 258 (S.D. Fla. 1981); In re Dominguez, 51 Bankr. 171, 173 (Bankr. C.D. Cal. 1985); In re Thacker, 48 Bankr. 161, 165 (Bankr. N.D. Ill. 1985); In re Jensen-Farley Pictures, 47 Bankr. 557, 583 (Bankr. D. Utah 1985); In re Baldwin-United Corp., 45 Bankr. 381, 382 (Bankr. S.D. Ohio 1984); In re Tolan, 41 Bankr. 751, 755 (Bankr. M.D. Tenn. 1984); In re Warrior Drilling \& Eng'g Co., 9 Bankr. 841, 848-49 (Bankr. N.D. Ala. 1981), modified, 18 Bankr. 684 (N.D. Ala. 1981). While no federal court of appeals has reached a contrary decision in a bankruptcy case, a few bankruptcy courts have held that time spent in preparing a fee application is not compensable out of the estate. See In re Holthoff, 55 Bankr. 36, 43 (Bankr. E.D. Ark. 1985); In re American Metals Corp., 49 Bankr. 579, 580 (Bankr. D. Kan. 1985); In re Trombley, 31 Bankr. 386, 388 (Bankr. D. Vt. 1983); In re Horn \& Hardant Baking Co., 30 Bankr. 938, 943 (Bankr. E.D. Pa. 1983). Examination of these opinions, however, indicates that they are devoid of any supporting argument for this holding. Further, these cases seem contrary to the spirit and the requirements of the bankruptcy rules. Under the rules, an attorney seeking compensation or reimbursement must provide the court with detailed statements and records supporting the request for fees. See FED. R. BANKR. P. 2016(a). Accurate and detailed fee applications aid in the proper and expeditious administration of the case and do not merely serve the self-interest of the petitioning attorney. See, e.g., In re Jensen-Farley Pictures, 47 Bankr. 557, 583 (Bankr. D. Utah 1985). 
pended in preparing the fee application, ${ }^{99}$ further depleting the pool of assets remaining for potential reorganization or satisfaction of unsecured creditors. In large bankruptcy proceedings, with sizable numbers of creditors, these expenses would be further multiplied. This does not comport with the sound bankruptcy policy of "keeping fees and administrative expenses at a minimuni so as to preserve as nuch of the estate as possible for the creditors." 100 Finally, because a motion for relief fron the autoniatic stay to file notice of intent to collect attorneys' fees will almost certainly be granted, ${ }^{101}$ requiring the creditor to go through these motions to reach a predetermined result unnecessarily accumulates fees for the sake of form over substance.

Of course, the inere fact that state law procedures are burdensome does not necessarily render then inconipatible with federal bankruptcy law, or autoniatically justify their preeniption. Where a state law fulfills its intended purpose, and that purpose is sufficiently weighty to justify application of state law, a bankruptcy court sliould not preempt the state law. ${ }^{102}$ Yet state law notice provisions snnply do not give the bankrupt debtor the protection that they were designed to provide. If, in sonie way, the debtor attempts to repay the creditor, such payment is unavail-

99. Compare the requirements of the seven-step procedure, supra note 96 , with those of the three-step procedure, supra note 97.

100. Otte v. United States, 419 U.S. 43, 53 (1974). See also Katchen v. Landy, 382 U.S. 323, 328 (1966) ("[A] chief purpose of the bankruptcy laws is to 'secure a prompt and effectual administration and settlement of the estate . . . " ") (quoting Ex parte Christy, 44 U.S. (3 How.) 292, 312 (1845)).

101. 11 U.S.C. $\$ 362$ (d) (1982) provides:

On request of a party in interest and after notice and a hearing, the court shall grant relief from the stay provided under subsection (a) of this section, such as by terminating, annulling, modifying, or conditioning such stay-

(1) for cause, including the lack of adequate protection of an interest in property of such party in interest....

If the creditor must comply with the notice provision in order to recover attorneys' fees, yet cannot comply without violating section 362(a), the ereditor's interest is clearly inadequately protected. The creditor could not take the steps necessary for recovery without receiving relief from the stay, even though it has a contractual right to recover the fees. Section 361(3) of the Bankruptcy Code provides that adequate protection can be provided, when required, by "granting such other relief . . . as will result in the realization by such entity of the indubitable equivalent of such entity's interest in sueh property." 11 U.S.C. $\$ 361(3)$ (1982). Granting relief solely to enable the creditor to file the required notice would be adequate protection of the creditor's interest, and the court can provide such flexible relief under section 362(d). See 2 Collier, supra note 23, If 362.07, at 362-49 ("[M]odification of the stay may be sufficient to protect the non debtor [sie] party by permitting the exercise of certain but not all of its rights...."). No reported case has presented any circumstances under which a court has denied a motion for relief from stay solely for the purpose of filing notice of intent to collect attorneys' fees as required by state statute.

102. See In re Quanta Resources Corp., 739 F.2d 912, 921-22 (3d Cir. 1984), aff'd sub nom. Midlantic Nat'1 Bank v. New Jersey Dept. of Envtl. Protection, 106 S. Ct. 755 (1986). 
ing because it is recoverable by the bankruptcy trustee. ${ }^{103}$ Because the debtor cannot repay the debt voluntarily, without the consent of the court, it cannot avoid the claim for attorneys' fees while in bankruptcy. Thus, a state law notice provision fails to serve the one meaningful purpose for which it was designed-protecting the debtor. ${ }^{104}$

Thus, the analysis under this branch of the preemption doctrine comes down to a balancing of objectives: protection of the debtor-as promoted by state notice laws, though frustrated by the intervening bankruptcy-against fairness to the oversecured creditor, efficient administration of the estate, and maximization of the estate for reorganization or hiquidation-as promoted by the Bankruptcy Code. State law notice requirements provide forinal procedural hurdles that merely produce delay and additional expense to the detriment of all parties involved in the bankruptcy proceeding. Because these state notice laws do not provide any meaningful additional protection for the bankrupt debtor, they should be treated as preempted in the context of bankruptcy proceedings, where they pose an unnecessary burden to creditors, the estate, and the bankruptcy courts. ${ }^{105}$

\section{CONCLUSION}

Courts have recently addressed the question whether section 506(b) of the Bankruptcy Code supplants state law notice provisions that govern the validity of contractual attorneys' fees obligations. Unfortunately, the language of section 506(b) does not expressly answer the question and the legislative history of the section, though providing plausible support for the conclusion that Congress intended to preempt state law, contains significant contradictions and ambiguities. Courts have struggled witl the issue without reaching a consensus. In doing so, courts have not considered the argument that federal preemption analysis dictates that state law is preempted if it is incompatible with the federal scheme and is not supported by strong state policy. Because notice provisions pose an unnecessary burden to creditors, the estate, and bankruptcy courts and fail to promote the state's objective of debtor protection, courts should

103. The trustee may avoid transfers of the debtor's property that occur after the filing of a petition in bankruptcy and are unauthorized by the court or the Bankruptcy Code. See 11 U.S.C. $\S 549(\mathrm{a})$ (1982).

104. See supra note 88 and accompanying text.

105. Cf. Dickerson v. New Banner Inst., 460 U.S. 103, 118 (1983) (in cases of statutory interpretation, task of court is "to interpret the words of [the statute] in light of the purposes Congress sought to serve"); Chapman v. Houston Welfare Rights Org., 441 U.S. 600, 608 (1979) (same); Philbrook v. Glodgett, 421 U.S. 707, 713 (1975) ("In expounding a statute, we must . . . look to the provisions of the whole law, and to its object and policy."). 
conclude that state notice provisions are not applicable in a bankruptcy proceeding.

R. Wilson Freyermuth 